\title{
Capitalist junctures: Explaining economic openness in the transition countries
}

\author{
THILO BODENSTEIN ${ }^{1} \&$ GERALD SCHNEIDER ${ }^{2}$ \\ ${ }^{1}$ Free University of Berlin, Germany; ${ }^{2}$ University of Konstanz, Germany
}

\begin{abstract}
Current transition theories attribute the varying economic openness of postcommunist countries to the lack of democracy or the inhibiting veto power of vested interests. In this article, the authors offer micro-foundations for such claims and link the key changes in the foreign economic policy of these states to internal coalition building during the first stages of the political transformation. A simple game-theoretic model demonstrates that the way in which ruling elites' responses to the competing demands of domestic stakeholders crucially shaped the chance of foreign economic liberalization years later. This 'early starter' hypothesis is contrasted with contending accounts of economic opening in multivariate tests using the ELITE data set (Economic Liberalization in Transition Economies). The regression models confirm that the scope of the political transformation process has fostered foreign economic openness, while the existence of veto players helps rather than inhibits the process of foreign economic liberalization.
\end{abstract}

\section{Introduction}

When in the fall of 1989 dissatisfied citizens gathered in Eastern Europe to protest against their authoritarian rulers, they obviously did not foresee most of the consequences their courageous actions would have some years later. No one knew then that most leaders would give up power relatively soon, and that the motherland of communism, the Soviet Union, would cease to exist within the next two years. Neither protesters nor the new rulers expected that the way in which the process of political opening took place would have important long-term repercussion in public policy making. We argue in this article that the foreign economic policies of the formerly communist states mirror these early events.

This article accordingly contends that the destiny of the foreign economic reform process crucially depends on the mode in which the political transformation took place. Countries that were able to break decisively with the influence of former rulers and establish new governing coalitions opened their economic systems much more than those states that remained tardy in the reform of their political system. As an established literature claims, the 
juncture in the political decision-making process crucially affected long-term patterns of public policy making (e.g., Colomer 1991; Przeworski 1991; Fish 1998; Frye 2002b; Frye \& Mansfield 2004). We add micro-foundations that establish a link between the political and economic reform processes to this argument.

Our explanation qualifies some standard explanations prevailing in the literature on economic openness. The transformation model we develop particularly qualifies the neo-institutionalist claim that the newly created 'rules of the game' influenced the likelihood of foreign economic liberalization. This literature suspects that the chances of reform are a negative function of the number of agents that are able block the implementation of new policies through formal or informal means (e.g., Tsebelis 1995, 2002). Although this veto player argument receives empirical confirmation for reform processes in established political regimes, we challenge its basic assumptions for the transition countries and argue that an increasing number of veto players may enhance rather than inhibit the scope of political reform. Because states had to make constitutional choices and key political decisions at the same time, the new power brokers supported rather than rejected the foreign economic liberalization of their countries if they were able to increase their power through such a move.

We develop our 'early birth' argument by integrating explanations that were developed largely independently from each other to explain the political and economic choices during the transformation process. Extending game theoretic models of democratic transitions allows us to analyze how the 'hardliner' faction in a communist regime deals with the double opposition from the 'softliners' within the ruling elite and the population in times of economic crises. The model analyzes this transition dilemma by assuming that the dominating faction in the Ancien Régime is able to allay this opposition through policy concession or by trying to stay in power by using force. The model traces the degree of openness back to the mode of transition. It particularly shows that countries that took an 'early start' by breaking forcefully with the communist regime had better options to implement sweeping reforms than 'latecomers', or regimes in which no substantial redistribution of power had taken place. Key for the understanding of 'honeymoon periods' (Balcerowicz 1994) is the replacement of the former elite. We hypothesize that the second mechanism of early and decisive democratization works through the installation of institutional veto players who shield a political regime against the possibility of a reform backlash.

The transition mode argument receives ample support in our multivariate analysis in which we rely on the Economic Liberalization in the Transitions Economies (ELITE) data set (Bodenstein et al. 2003). In contrast to extant measures of foreign economic openness, the ELITE variables capture the 
degree of actual regulation rather than real trade flows. We present an economic background condition model as the baseline and contrast it with several competing hypotheses of economic openness. The 'early starter' and the adapted veto player model we introduce are superior to alternative explanations. The article is structured as follows: We first discuss the contending accounts of economic openness. Next, we outline our own critical juncture argument and derive the hypotheses to be tested. We then present our research design, followed by an evaluation of the dimensions of economic openness with the help of the ELITE data set and test the explanatory models statistically. The final section contains our conclusions.

\section{Theoretical explanations of economic reforms}

One of the main conjectures in the ever-expanding literature on globalization is that states become more similar under the pressure of an increasingly competitive world market. This conjecture is, however, not only wrong for the industrialized world where a variety of 'capitalisms' have emerged over the last decades, as at least one group of scholars observes (Kitschelt et al.1999), it also seems to be inadequate for transition economies that are bound together by a common history of communist rule and which, at least initially, faced similar economic and social problems (Åslund 2002).

A few examples suffice to show how diverse the foreign economic policies of these states are. The Baltic republics, for instance, have followed a relative consistent course of liberalization. Conversely, the track record of the two main powers in this region - Poland and Russia - is rather mixed. Poland removed some of its non-tariff barriers to trade between 1993 and 2000, but left its capital controls at a relatively high level. Russia became more protectionist on both dimensions of foreign economic policy making in the second half of the 1990s (Bodenstein et al. 2003).

Four main types of explanations try to account for the bewildering diversity in the success of economic reform efforts. Although these arguments relate to overall economic policy, they also encompass foreign economic reforms. From a politico-economic point of view, foreign economic reforms aim at restructuring the economy and entail similar distributional consequences to domestic economic reforms (Drazen 2000: 620). Before we develop our own argument, we will present these contending accounts. ${ }^{1}$

\section{Economic crisis}

It is a widespread belief that economic crisis triggers reform (Drazen \& Easterly 2001). Haggard \& Kaufmann (1995) see in an aggravating economic 
situation the main condition for breaking up 'distributive coalitions' that impede reforms. This explanation accordingly draws on the changes that the incentive structure of different sets of actors undergoes in times of economic crisis. Proponents of this view believe that the growing costs of the status quo prompt a crisis-ridden country to embark more or less automatically on a course of macroeconomic stabilization and economic openness. Ample illustrative evidence seems to support the argument that foreign economic liberalization is a consequence of aggravating domestic problems. Some scholars argue in this vein that economic reform in Latin America followed the severe debt crises of the 1980s (Bates \& Krueger 1993).

Even though this explanation is straightforward, it is not innocuous. The first problem has to do with the apparently irrational delays that occur in crisis-ridden countries. It is well-known that the communist countries faced economic problems at least since the early 1980s, yet the reforms only began much later and have not yet been fully implemented in some states. It is not surprising that several observers have challenged the crisis argument for its inability to explain the delay of crucial reforms (e.g., Alesina \& Drazen 1991). A second weakness of the crisis thesis is its functionalist logic; hence, it is $e x$ post always possible to trace the liberalization of an economy back to worsening economic conditions even if the detrimental changes are more anticipated than real.

Unsurprisingly in light of these and other analytical challenges, alternative explanations that equally focus on the structure of the economy have been developed. To give an example, De Melo et al. (1997) claim that the initial economic conditions of a country largely explain the scope of its economic reforms. This interpretation is widely shared in policy circles. The European Bank for Reconstruction and Development contends that 'differences in initial conditions play a major role in explaining why some countries fared so much worse than others in the first phase' (EBRD 1999: 62).

\section{International influences}

A second strand of reasoning points to the influence of international donor organizations in the economic reform process. Since the creation of the Bretton Woods Institutions (BWI), conditionality has been a major component of structural adjustment lending (Mosley 1992). In its first phase, conditionality entailed predominantly structural reforms of financial and monetary institutions. After the more transparent codification of their mission in the 1960s, the BWIs explicitly demanded trade liberalization as a condition for financial aid (Mosley et al. 1991; Guitian 1995). The aim of conditionality was 'to buy reforms' (Collier 1997). 
The success of conditionality programs is, however, rather mixed. Some scholars established a negative impact of conditionality in developing countries (Sachs 1989). Harrigan (1996) accuses the BWIs of being 'toothless tigers' and having failed to implement structural reforms. Dicks-Mireaux et al. (2000) report a negative correlation between International Monetary Fund (IMF) conditionality and inflation, while Bordo \& Schwartz (2000) discover no correlation at all. Burnside \& Dollar (2000) find a positive impact of international aid on growth if the macroeconomic policies in the recipient country are convincing. Taking the failure of conditional lending into account, Taylor (1997) suggests 'reverse conditionality' as a new precondition for international financial cooperation where countries, instead of the BWIs, propose the economic reform programme they want to achieve.

Although conditional lending is widely discussed for the developing countries, its effects on the structural reforms of the transition countries are still not clear. Dabrowski (1998: 181) argues that the lending allocations in the formerly communist world show a 'large asymmetry in the geographical distribution of aid'. This pattern may be due to strategic lending (Lundborg 1998), where the IMF fails to withhold a tranche when a 'strategic' country does not fulfil its obligations. Russia, especially, profited from the IMF's reluctance to punish non-compliance and received disproportionately high loans (Stone 2002).

\section{Vested interests}

The third line of thought relates to the role that interest groups play during the transition phase. Many observers have attributed the dire state of some transition economies to the rent-seeking activities of 'vested interests'. One prominent proponent of this view was Olson $(1996,2000)$. The main reason why 'big bills are left on the sidewalk' (to quote an influential article by him) is the disproportional influence of what he called 'distributional coalitions' (Olson 1982). Even though society would profit from a political change, specialized interest groups are able to organize themselves efficiently and block the reform process. The initial impediment to reforms lies accordingly in the failure of distributing early losses among actors (Martinelli \& Tommasi 1997). Alesina \& Drazen (1991) offer a game theoretic extension of this argument and show how the 'war of attrition' into which two competing interest groups engage is a fundamental cause for the delay of policy reforms. As the authors convincingly point out, distributional conflicts are 'resolved' if one side gives in and is willing to unilaterally pay the costs of reform.

The most common way to model interest group influence is to assume that lobbies pay contributions that politicians invest for their campaigns (Ben-Zion \& Eytan 1974). Building on the concept of politics as a market, Magee et al. 
(1989) show how suboptimal protectionist policies are a by-product of a political exchange in which the government 'sells' protection for campaign support from interest groups. More recent models focus on influence via information processing by interest groups, bribes or legal proceedings (Grossman \& Helpman 2001).

Hellman (1998) argues in line with Olson that the 'early winners' of the transition process often become the new rent-seekers who prevent the adoption of further measures. Hellman et al. (2003) find empirical evidence that many transition countries are captured by vested interests. Furthermore, Hellman \& Schankerman (2000) show that economic reforms have limited effect once a country is captured by vested interests. Frye (2002a) argues that lobbying success depends on the type of government. We nevertheless posit the hypothesis that the possibility that one group seizes the state corresponds largely to the economic structure of a state. If the influence of the subsidized sectors is large, it is easier for protectionist forces to capture rents. The more empowered these interest groups are, the more they should be able to retard the process of foreign economic liberalization.

\section{Institutions}

Several theoretical strands suggest that institutional impediments matter for the explanation of key policy reforms (Bates \& Krueger 1993; McFaul 1995; Migdal et al. 1994). Different institutional characteristics might play an important role in foreign economic decision making. Recent research by Bueno de Mesquita et al. $(1999,2002)$ suggests that institutions are key in democratic and autocratic regimes. Bueno de Mesquita and his co-authors develop a noncooperative game to model the trade-off a government faces in fulfilling the wishes of what they call the 'selectorate' (the group that chooses the government) and the winning coalition. Political participation is crucial in this model because enlarging the winning coalition guarantees a higher production level for growth-enhancing public goods. ${ }^{2}$ If we take these insights seriously, we need to take a closer look at the role that veto players have in the economic reform process of democratizing countries.

The transformation literature discusses in this vein whether democracy is more conducive to economic reforms than autocracy. Several scholars argue that autocratic regimes are better able to induce reforms because they are institutionally isolated from outside pressure to postpone reforms (Haggard \& Webb 1994; Hellman 1998; Gordon 2000). The economic success story of the Asian countries until the financial crisis in 1998 seemed to underpin the 'authoritarian advantage' for sustainable economic reforms. The insulation argument can be linked to the insights of the more formalized veto player 
theory (Tsebelis 1995, 1999, 2002). Tsebelis (1995: 293) understands 'veto player' to be 'an individual or collective actor whose agreement is required for a policy decision'. His principal claim is that the stability of a given policy status quo is a function of the number of both institutional and informal veto players such as second chambers, political parties and interest groups, and the preferences these actors have. A given status quo will be stabilized by the number of veto players, the distance between their ideal points and the coherence of each veto player. According to this logic, authoritarian regimes are characterized by the lack of 'checks and balances', and therefore by less or no veto players, which should make them more conducive for reforms.

The 'deadlock argument' seems, however, empirically untenable. Democratic transition countries are more successful with their economic reforms than their autocratic counterparts. The veto player argument is, in our view, mainly valid for countries in which the institutional and party structure is 'frozen'. These are the stable and long-lasting democracies that one typically finds in the OECD area. The transition countries, by contrast, were still in flux institutionally in the 1990s (Mair 1997; Lewis 2000). Some of their basic characteristics were high voter volatility and frequent electoral replacement of parties. Government coalitions were consequently highly unstable, and shifting coalitions were often able to surmount the alleged deadlock situations. In this volatile environment, coalitions for reform were easier to craft than in wellestablished Western party systems. One of the main disadvantages of democratic governments - lack of insulation - was therefore softened by a fluid party system that de-emphasizes the role of partisan veto players.

Our refined version of the veto player theory stipulates that democratically legitimized veto players may be better able to meet the welfare demands of the population than authoritarian veto actors. We can base this counter-intuitive expectation on an alternative veto player model that Persson et al. (1997) put forward and that Tsebelis (2002) qualifies negatively. Assuming a Downsian logic, these authors conceive of veto players as 'office seekers' who have to take the demands of the median voter into account in order to survive politically. Because the median voter holds the veto players collectively responsible for welfare losses, veto players have no incentive to 'oversupply' their supporters with goods at the expense of other social groups. This argument, however, only holds for institutional veto players who strive for re-election. Informal veto players such as interest groups or occasional veto players in particular policy areas such as central banks are not expected to deliver welfare-enhancing policies as they do not compete in national elections. The policies that are adopted under such a check-and-balance system are likely to converge on the welfare position of the median. Governments that face many veto players are more likely to choose the socially optimal policy 
option than executives with large discretionary power. Frye \& Mansfield (2003) provide some evidence in support of this conjecture. This empirical association awaits, however, a theoretical foundation. In the following, we develop a game theoretic version of the critical juncture argument to account for the diversity of foreign economic policies.

\section{The significance of critical junctures in a game theoretic perspective}

A number of studies explain why the transition countries have made different constitutional choices (Lewis 1997; Munck \& Skalnik Leff 1997; Easter 1997; Bunce 2000,2003). These examinations focus on a wide set of variables, but do not pay much attention to the differing strategic context in which these decisions were made. We believe that the possibilities and limitations that the early transition process offered has important consequences for the foreign economic policy choice of the governments. In the early stage of the transition process actors could not take the institutional setting for granted. This impossibility necessitates the introduction of a model that goes beyond the standard institutionalist account that tries to correlate regime type or the presence of varying numbers of veto players with the political inertia of a state. Our model follows the rich literature on the role of 'critical junctures' for democratization and economic reforms (e.g., Przeworski 1991; Fish 1999; Acemoglu \& Robinson 2001).

At the time of economic transition, the post-communist regimes underwent far-reaching political change. Several scholars have explored the constraints and path dependencies that the mode of regime change brought about. Colomer $(1991,1995)$ claims that the interactions between government elites, reformers and the population determined, to a considerable extent, the institutional setup in the aftermath of the founding elections. Institutional reform is backward in countries where the old political forces controlled the democratization process. McFaul (2002) contends that the degree of post-communist democratization is a function of the balance of power between former elites and their democratic challengers. Fish (1998) argues that communist electoral success and the extent of democratic change ought to influence the path of economic reform. In a similar vein, Frye (2002b) shows that political polarization between anticommunist and post-communist parties lowered the economic growth rates in transition countries. Frye \& Mansfield (2004) empirically corroborate the close link between elections and trade liberalization in the transition countries.

The critical juncture game that we develop builds on this literature and assumes that a 'hardliner' and a 'liberalizer' faction build up the incumbent authoritarian regime. The preferences of these competing groups over the 
political and economic future of their country differ in important ways. While the hardliners are setting the tone and are thus closer to the status quo than the other groups, the liberalizers are predominantly interested in the economic opening and possible windfall rents they gain from it. The domestic constituents as the third important group have a strong preference for a transition to democracy, but they oppose radical economic openness, not the least because they are negatively affected by it in the short run.

The 'Transformation Game' allows us to derive precise hypotheses about the impact that the transformation mode has on the degree of economic openness in a transition economy. Figure 1 presents the game in extensive form. We denote the hardliner faction within the government as player $\mathrm{H}$, the opposing softliner faction as player S. Domestic constituents are represented through the preferences of the median voter M. To analyze the game, we will first specify the sequence of moves, then introduce the parameters, discuss possible preference orders and finally solve by backward induction.

The game starts out with a move by $\mathrm{S}$ that either demands an economic opening of the economy or refuses to do so. If such a request is formulated, the dominating hardliner faction simply says 'yes' or 'no'. If they accept, the median voter has the chance to go further and ask for a democratization of the regime. If they do not ask for institutional reforms, the game ends. In the event that a democratization movement forms, the government makes a binary decision. If

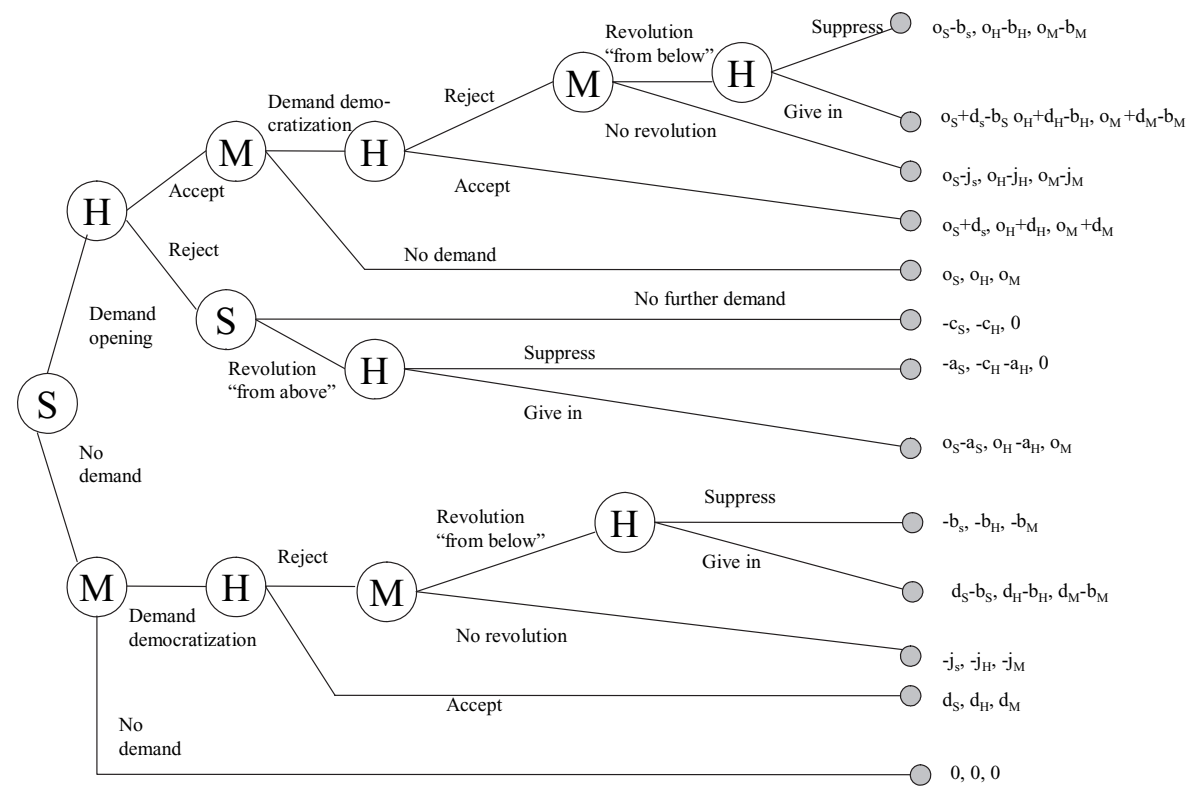

Figure 1. The Transformation Game. 
it accepts the demand, the game ends and the country experiences a double and peaceful reform. A 'revolution from below' becomes possible in the event of a refusal. $\mathrm{M}$ then decides whether it brings its request to the street. A decision in this direction yields the hardliner faction the possibility to choose between suppressing the revolution and giving in to popular demand. If the median voter backs down, the game ends without an institutional transformation.

The upper part of the game looks different when the hardliner faction initially refuses to give in to the demand of the softliner faction. $S$ then decides whether or not it initiates a 'revolution from above' or whether it prefers to live with the status quo in the organization of the economy. The hardliner faction has a binary choice between suppressing the 'palace revolt' or not. The game ends with both moves by $\mathrm{H}$. The game reduces to a democratization game if $\mathrm{S}$ does not demand more economic openness. $\mathrm{M}$ then has the chance to ask for democratization or not. If it does not utter a request, the Transformation Game ends trivially with the status quo. The demand for democratization, by contrast, yields $\mathrm{H}$ the option to either suppress the popular movement or accept its demands. If this faction refuses to give in, it is again up to the median voter whether or not they intend to initiate a popular movement. The hardliner faction decides in the end whether the 'revolution from below' is successful.

The parameter $d_{i}$ is the payoff an actor receives for democratization, $o_{i}$ stands for the opening payoff. If a demand is not fulfilled, its initiator has to bear certain costs: $-c_{i}$ is the cost of a refused demand for economic opening and $-\mathrm{j}_{\mathrm{i}}$ the costs of a rejected request to democratize the country. Parameters representing costly actions by an actor or their equally costly consequences for the other actors include the costs $a_{i}$ of a revolution from above, and $b_{i}$ of a revolution from below. The status quo payoff is denoted as 0 .

We will introduce two types of softliners and median voters as well as three types of hardliners to explore different transition modes. To start with, we distinguish between determined and bluffing softliners according to whether or not they have a credible threat to carry out the palace revolt. The credible threat of a determined softliner implies that this player prefers a suppressed demand over the costs of a rejected demand to open the economy. Condition (i) describes determined softliners, condition (ii) bluffing softliners.:

$$
\begin{aligned}
& \text { i) }-\mathrm{a}_{\mathrm{S}}>-\mathrm{c}_{\mathrm{S}} \\
& \text { ii) }-\mathrm{c}_{\mathrm{S}}>-\mathrm{a}_{\mathrm{S}}
\end{aligned}
$$

Hardliners have to face potential challenges from the softliner faction or a public protest movement. They can either: reject both demands, accept the demand from the softliners or give in to both sides simultaneously. ${ }^{3}$ The 
following preference assumptions summarize the preference orders of what we call 'resistant', 'gulash' and 'wimpy' hardliners.
i) $-b_{\mathrm{H}}>-\mathrm{d}_{\mathrm{H}}$ and $-\mathrm{c}_{\mathrm{H}}-\mathrm{a}_{\mathrm{H}}>\mathrm{O}_{\mathrm{H}}$
ii) $-b_{\mathrm{H}}>-\mathrm{d}_{\mathrm{H}}$ and $\mathrm{o}_{\mathrm{H}}>-\mathrm{c}_{\mathrm{H}}-\mathrm{a}_{\mathrm{H}}$
iii) $-\mathrm{d}_{\mathrm{H}}>-\mathrm{b}_{\mathrm{H}}$ and $\mathrm{o}_{\mathrm{H}}>-\mathrm{c}_{\mathrm{H}}-\mathrm{a}_{\mathrm{H}}$

The median voter, finally, either has a credible revolutionary potential or not. Conditions (i) and (ii) of Equation (3) describe these two basic types.

$$
\begin{aligned}
& \text { i) }-b_{M}>-c_{M} \\
& \text { ii) }-c_{M}>-b_{M}
\end{aligned}
$$

An additional assumption is $-\mathrm{c}_{\mathrm{H}}>\mathrm{O}_{\mathrm{H}}$. It ensures that it costs less to reject a demand by the competing faction in the government than to give in. If we assume complete information, it is easy to calculate the sub-game perfect equilibria for the twelve possible preference configuration (the derivations can be obtained from the authors upon request). Table 1 summarizes the outcomes we expect under the varying preference configurations.

Under complete information, the Transition Game entails equilibria that describe the full range of outcomes of the transition countries. While some states neither opened up nor exchanged the protectionist ruling elite, other countries followed a pact-like transition strategy. Such a compromise typically involves a compromise between the domestic constituents and the more risk-prone parts of the population. Pacts have, however, the problem that the former rulers still have some clout and delay the implementation of the reform process. We thus expect in line with Olson (1982) that a radical break with the past ensures that

\begin{tabular}{|c|c|c|c|c|}
\hline & $\begin{array}{c}\text { 'Democratic' } \\
\text { softliners }\end{array}$ & $\begin{array}{l}\text { 'Resistant' } \\
\text { hardliners }\end{array}$ & $\begin{array}{l}\text { 'Gulash' } \\
\text { hardliners }\end{array}$ & $\begin{array}{l}\text { 'Wimpy' } \\
\text { hardliners }\end{array}$ \\
\hline \multirow{2}{*}{$\begin{array}{l}\text { Softliners with } \\
\text { credible } \\
\text { threat }\end{array}$} & $\begin{array}{l}\text { Median with } \\
\text { credible threat }\end{array}$ & Status quo & $\begin{array}{l}\text { Economic } \\
\text { openness only }\end{array}$ & $\begin{array}{l}\text { Double } \\
\text { transition }\end{array}$ \\
\hline & $\begin{array}{l}\text { Median without } \\
\text { credible threat }\end{array}$ & Status quo & $\begin{array}{l}\text { Economic } \\
\text { openness only }\end{array}$ & $\begin{array}{l}\text { Economic } \\
\text { openness only }\end{array}$ \\
\hline \multirow{2}{*}{$\begin{array}{l}\text { Softliners } \\
\text { without } \\
\text { credible threat }\end{array}$} & $\begin{array}{l}\text { Median with } \\
\text { credible threat }\end{array}$ & Status quo & $\begin{array}{l}\text { Political change } \\
\text { only }\end{array}$ & $\begin{array}{l}\text { Political change } \\
\text { only }\end{array}$ \\
\hline & $\begin{array}{l}\text { Median without } \\
\text { credible threat }\end{array}$ & Status quo & Status quo & Status quo \\
\hline
\end{tabular}

Table 1. Sub-game perfect equilibria 
the old distributional coalitions are considerably damaged. Countries that embarked on a swift change to a democratic regime and banned the postcommunists from participating in the government at least for some years thus have the better track record in reform of their foreign economic policies.

The model implies also that democracy is not a cause of economic openness, but rather a consequence of the way in which the transformation process took place. A double transition is likely if both the society and the softliners are powerful. An incomplete transformation materializes if either one of the opposing forces does not possess a credible threat. Reduced economic openness is also possible in the event that the hardliners prefer to co-opt the opposing softliners into the political system, but prefer to leave civil society outside the government. Obviously, the credibility of a threat by the two challengers is influenced by the way in which the actors manipulate their credibility. Whether an actor is able to pursue the preferred strategy depends upon his or her resources. This endowment makes it likely that a protest movement coming out of a strong civil society is better able to signal its resolve than the protesters from a country with low social capital.

Our game adds to the explanations of why countries are successful in reforming their economies. Our empirical examination will try to evaluate their relevance. Table 2 summarizes the hypotheses we derive from the model and the extant literature. We add to the five independent variables a concept that should help us to take into account that countries are exposed to the conditions and demands of the world market to different degrees. According to Alesina \& Wacziarg (1998) and many others, small countries are economically more open than large economies because the former cannot equally profit from their domestic market.

Table 2. Hypotheses

\begin{tabular}{|c|c|}
\hline Theory & Hypothesis \\
\hline Economic crisis & $\begin{array}{l}\text { H1: The more severe the economic crisis, the more wide-ranging } \\
\text { the foreign economic reforms of a country. }\end{array}$ \\
\hline International aid & $\begin{array}{l}H 2 \text { : The more international financial aid a country receives, the } \\
\text { more wide-ranging the foreign economic reforms of a country. }\end{array}$ \\
\hline Vested interests & $\begin{array}{l}\text { H3: The more influential interest groups are, the less } \\
\text { wide-ranging the foreign economic reforms of a country. }\end{array}$ \\
\hline Veto players & $\begin{array}{l}\text { H4: The higher the number of veto players, the more } \\
\text { wide-ranging the foreign economic reforms of a country. }\end{array}$ \\
\hline Transition mode & $\begin{array}{l}\text { H5: The more democratic the early elections, the more } \\
\text { wide-ranging the foreign economic reforms of a country. }\end{array}$ \\
\hline
\end{tabular}




\section{Research design}

We will test the competing hypotheses on economic openness with the help of the new cross-sectional ELITE (Economic Liberalization in the Transition Economies) database. This new data set covers the time period from 1993 to 2000 for 24 East European post-communist and former Soviet Union countries (Bodenstein et al. 2003), which is also the temporal and geographical scope of this study. ${ }^{4}$ We will now describe this and the other data sets we used, operationalize the variables and list their sources. We will then summarize our estimation technique.

\section{Outcome variable}

In order to measure the extent to which a country has imposed regulatory trade reforms, the ELITE data set largely follows the logic of Quinn's (1997) coding procedure. He used the IMF Annual Report on Exchange Arrangements and Exchange Restrictions for the creation of his data. Indicators based on administrative measures have the advantage that they directly measure political choice instead of aggregated outcomes such as trade or capital flows that are also influenced by non-political factors. Nevertheless, administrative measures tend to over-emphasize the constraining effects of laws and other regulations on trade flows. Countries are, for instance, coded as having licenses' even if only a small part of the external trade is exposed to licensing requirements. Yet, as we rely on an index, the possible bias of some indicators that went into it might not be too grave.

The ELITE data set is more comprehensive than the unidimensional Quinn (1997) measure and comprises 19 dummy variables on a whole set of policy measures. Our openness measure, ELITE, is the composite overall foreign economic openness score. We simply constructed it by dividing our two sub-indices for trade and capital by the number of their items in order to control for missing values and added both variables into our single ELITEindex. ${ }^{5}$ We mirrored the original ELITE data so that the higher the score, the more open the foreign economic regime.

\section{Independent variables}

The independent variables of primary interest for our empirical inquiry are the kind of regime transition and the veto player structure of the political system in post-communist countries. As far as we had to code variables on our own, we 
relied on the German edition of Keesing's Contemporary Archives (Vols. 59-65) and Klingemann and Taylor (1995-2002).

\section{Transition mode}

To test our main hypothesis, we use the FELEC measure developed by Fish (1998) to capture the essential cross-country differences of the transition mode. FELEC summarizes information about the outcome of the first elections in the aftermath of a regime's collapse. Fish constructed an ordinal scale with six categories, and distinguished whether the first elections were competitive and free and whether the incumbent elite or the new democratic challengers won the elections. He added scores according to the following rules: winners of elections (reformers $=2$, equivocal outcome $=1$, communists $=0)$, quick annulation of elections $(\mathrm{no}=1$, yes $=0)$, open elections with multiple candidates (yes $=1$, no $=0$ ), completeness of elections (complete elections $=1$, partial elections $=0$ ). The maximum score depicts free and fair elections the reformers won, whereas undemocratic founding elections received a score of zero. We recoded FELEC into four categories because the original five items were unevenly distributed among the transition countries under examination and fused scores from 0 to 2 into a single category.

\section{Veto players}

We decided to examine the impact of veto players along three dimensions: presidential strength, executive constraints and bicameralism. For the first dimension, we used a measure for the index of presidential power (IPP) constructed by Spörer (2004). IPP includes three aspects of presidential power: legitimacy, legislative competencies and non-legislative competencies, and varies between 0 and 1 . High scores depict more presidential power. The expected sign of presidentialism is, as indicated, not clear. In the tradition of Lijphart's (1999) seminal classification, we also use an index of executive constraints. Executive constraints (XCONST) is a variable taken from the Polity IV database (Jaggers \& Gurr 1995). It measures the extent to which the decision-making powers of individual or collective chief executives are constrained. Higher scores are related to more veto points in the institutional structure. In addition, we use a dummy variable for bicameralism (BICAM). Values of $B I C A M$ of 1 (0) indicate whether (or not) the post-communist polity has a second parliamentary chamber. 


\section{Interest groups}

Sectoral shares are the best proxies we could find to test for interest group influence in our set of countries. The share of the service sector (SERVICE) is available for most transition countries from the World Development Indicators (World Bank 2002). Unfortunately, we could not use the share of the manufacturing sector because of missing data.

\section{International aid}

To test for the influence of international credits and aid, we included the logarithm of the credits from the World Bank organizations IDA and IBRD (WORLDBK log) as well as the logarithm of the amount of international aid per capita (AID/Cap log). Data is taken from the World Bank (2002).

\section{Economic crisis}

In order to account for the strength of an economic crisis we used the yearly growth rates of GDP of the previous year $\left(\Delta G D P_{t-1}\right)$ of each country. We took the data from the World Bank (2002).

Size of the economy

Alesina \& Wacziarg (1998) argue that larger economies are less open than smaller ones. We use the size of the economy measured as the logarithm of the GDP $(G D P \log )$ in order to control for this effect. Data is provided by the World Bank (2002).

\section{Independent and control variables}

Table 3 summarizes the independent and control variables and shows the hypothesized effects. Remember, for the interpretation of the expected signs, high values of the dependent variable depict more open foreign economic regimes. Appendix 1 summarizes the descriptive statistics for the independent variables, and Appendix 2 presents the bivariate correlations between the independent variables.

\section{Model specification}

Our data set covers the years from 1993 to 2000 and is thus a time-series cross-section (TSCS). As the standard OLS assumption of homoscedasticity is 
violated, Beck and Katz (1995) propose the use of an OLS model with panelcorrected standard errors that also controls for spatial simultaneous autocorrelation. They also advocate the inclusion of the lagged dependent variable on the right-hand side of the equation to overcome the problems of temporal dependence. This procedure, however, has some drawbacks. The inclusion of the lagged dependent variable, as Achen (2000) points out, leaves only a little variance to be explained by the independent variables of substantial interest. To solve the problem of serially correlated errors of our panel data, we use the Prais-Winsten method advocated by Plümper et al. (2005). In case of serial autocorrelation, the estimators are no longer efficient and estimated standard errors will be biased downward, especially when the number of periods is small. The suggested Prais-Winsten transformation eliminates serial autocorrelation. The error structure can be correctly estimated using the first-difference equation as regression model satisfying the standard OLS assumptions. By applying this method, however, the first observation gets lost. The Prais-Winsten transformation includes the first observation by an estimating procedure for it (Gujarati 2003: 678). Eventually, estimated standard errors are unbiased and the estimator is efficient. An important side effect of the Prais-Winsten transformation is that it reduces the serial correlation of the errors and makes them amenable to tests of our rather static hypothesis.

In order to detect serial autocorrelation in our data set, several tests can be performed. We ran the augmented Dickey-Fuller (ADF) test, which seems the most adequate test given our data structure. ADF is a unit root test and assumes correlated error terms and controls for their effect by adding lagged values of the (first difference) dependent variable. The critical test value of

Table 3. Variable definitions and hypothesized signs of effect

\begin{tabular}{lllc}
\hline Theory & Variable abbreviation & Variable short name & $\begin{array}{c}\text { Hypothesized } \\
\text { sign of effect }\end{array}$ \\
\hline Transition mode & FELEC & First elections & + \\
Veto player theory & $I P P$ & Presidentialism & + \\
Veto player theory & $X C O N S T$ & Executive constraints & + \\
Veto player theory & BICAM & Bicameralism & + \\
Interest groups & $S E R V I C E$ & Size of service sector & + \\
International aid & $W O R L D B K(\log )$ & World Bank loans & + \\
International aid & $A I D / C a p(\log )$ & Aid per capita & + \\
Country size & $G D P(\log )$ & Size of GDP & - \\
Economic crisis & $\triangle G D P_{t-1}$ & Growth rate & - \\
\hline
\end{tabular}


ADF derives from the $\tau$-statistic. If $\tau$ exceeds the critical values, there should be no serial autocorrelation; otherwise serial autocorrelation has to be assumed. The ADF test revealed that our data are subject to serial autocorrelation, which has to be corrected by the Prais-Winsten transformation.

\section{Foreign economic reforms: Results of the statistical tests}

The Elite database yields a rather mixed picture of the reform record of the transition countries (Bodenstein et al. 2003). Although trade reforms proceeded well on average, most of the transition countries introduced constraints on their capital accounts in the course of the 1990s. If we add, however, both trade and capital reforms into a single foreign economic openness index (ELITE), the average transition country pursued a clear opening strategy. Figure 2 shows, in the form of box plots, how the reform process took place.

The transition countries constantly reduced the restrictions on international trade and capital transfers from 1993 to 1996. Yet, the overall opening

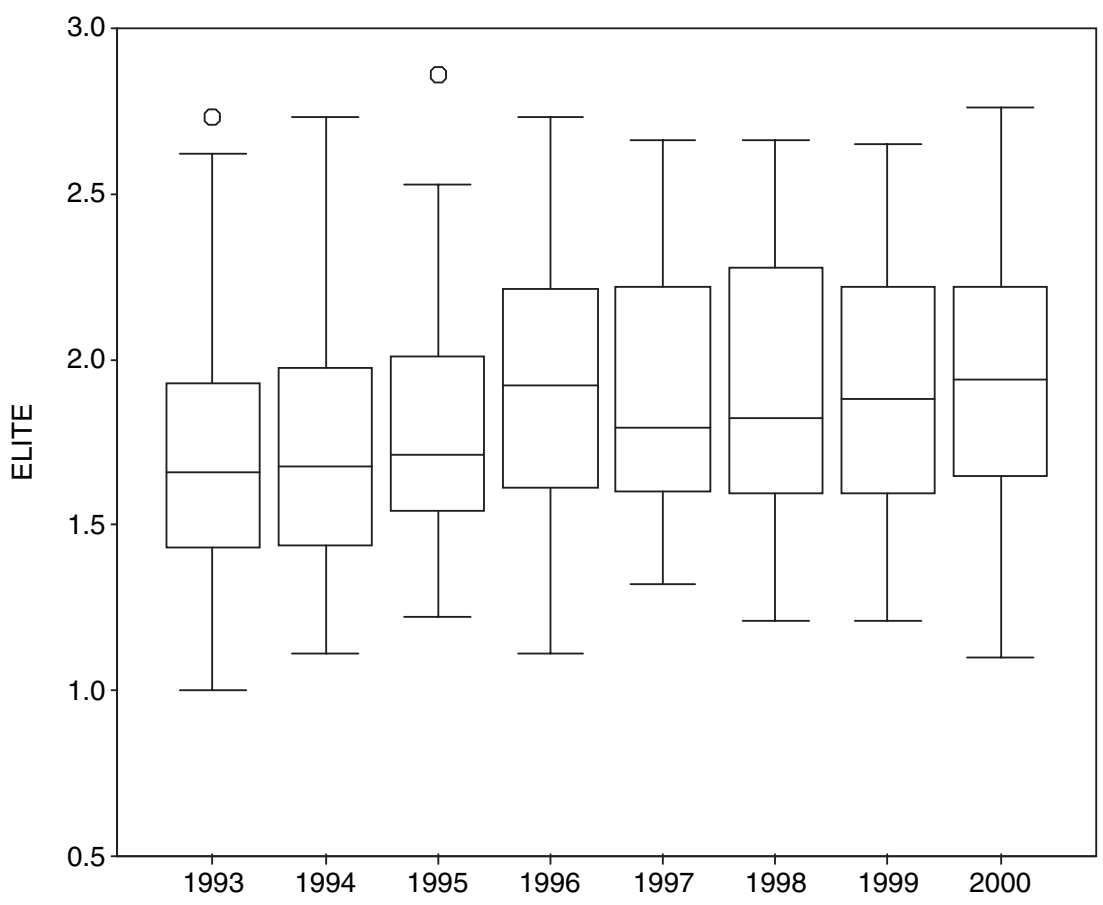

Figure 2. Foreign economic openness (ELITE) by year. 
process slowed down in 1997 because some countries re-introduced capital controls following the Asian crisis. As Figure 3 demonstrates, Latvia, Armenia and Estonia were the most open countries in 2000, whereas Ukraine, Uzbekistan and Belarus formed the group with the most restrictive foreign economic regimes. The transition countries have a very mixed reform record: some opened up their foreign trade regimes quickly, whereas other countries stayed closed or introduced more controls on their foreign economic sector. Following the introduction of more controls in the aftermath of the Asian crisis, the transition countries regained their reform impetus and followed the path of liberalization. On average, the European Union accession countries liberalized their external trade regimes more than the Commonwealth of Independent States (CIS) countries (Åslund 2002).

If we take a closer look at Figure 3, much more variation in the foreign economic reform process becomes apparent. For example, Kyrgyzstan was the most open country in the last decade and nearly eight times more open than Ukraine - one of the most closed countries. Poland, frequently quoted by the reform indices of the EBRD Transition Reports (EBRD 1993-2000) as a success story, is about six times more closed than Kyrgyzstan and finds itself only slightly more open than Kazakhstan and Russia during this period. Variations within each country differ sharply with Estonia, Armenia and the Czech

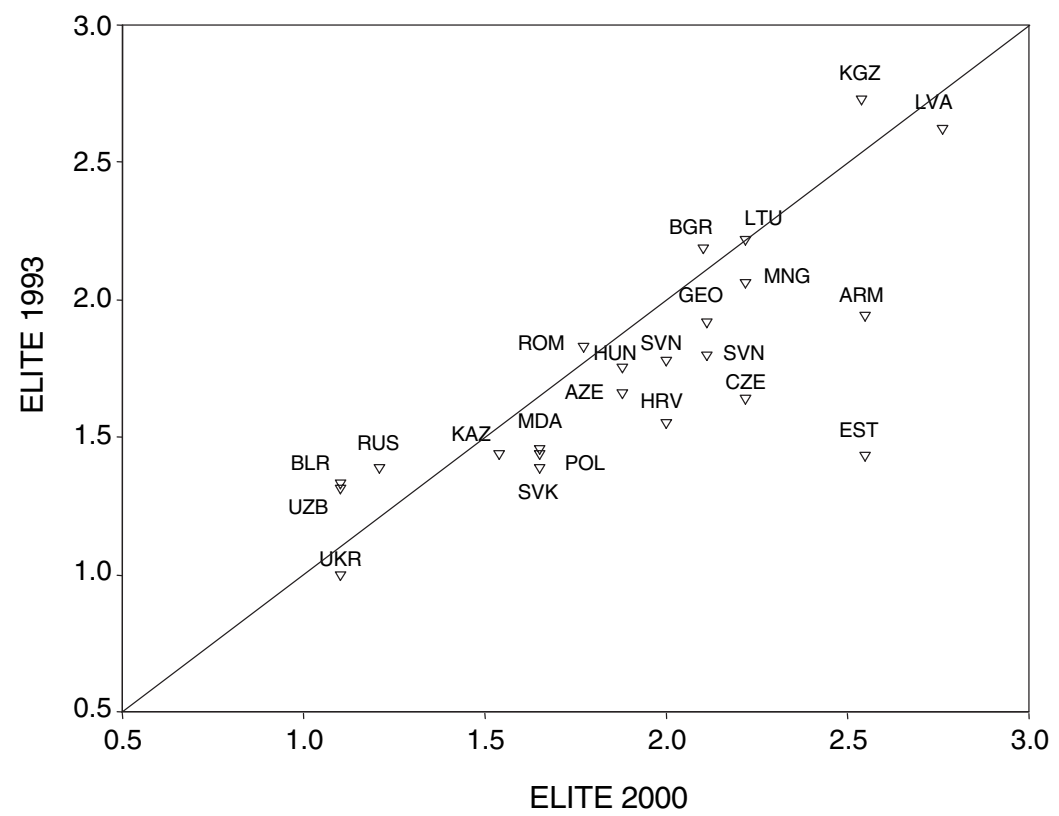

Figure 3. Foreign economic openness (ELITE) by country. 
Republic having the largest standard deviation. The reform figures are almost constant in Lithuania, Latvia and Romania, revealing that the first two were either relatively open from the beginning of the process or stayed rather closed like Romania.

We will try to explain in the following why some countries managed to open their foreign economic regimes, whereas others failed to integrate into the world market. We use the size of the economy (GDP log) as our baseline model and proceed by integrating additional independent variables derived from our theoretical discussion. Table 4 provides the results for the baseline, the crisis and the first elections models. The estimations reported in Table 4 show the expected negative and significant relationship between the size of the economy and the openness of the foreign trade regime. As the theory leads us to expect, large economies tend to be more closed than small ones. ${ }^{6}$ We find that the economic crisis argument does not have the expected explanatory power. The sign of the growth rate in model 2 points in the opposite direction to that suggested by the crisis hypothesis. Consequently, the influence of macroeconomic performance on trade and capital openness is more complex than this standard explanation would have it. In some countries, good economic performance rather than crisis seems to be a prerequisite for foreign economic reforms. Armenia, for instance, closed its economy when its growth rate dropped sharply in the beginning of the transition process. When its macroeconomic performance slightly recovered after 1994, it heavily liberalized its foreign economic regime. Both Azerbaijan and Georgia followed this pattern and only liberalized after they had stabilized the economy. Latvia, on the other hand, never closed its foreign economic regime despite a sharp decline in the growth rate in the early 1990 s. $^{7}$

Table 4. Economic predictor variables of economic openness

\begin{tabular}{|c|c|c|c|}
\hline & Model 1 & Model 2 & Model 3 \\
\hline Constant & $4.449 * * * \quad(7.73)$ & $4.758 * * *(10.71)$ & $4.942 * * *(8.83)$ \\
\hline$G D P(\log )$ & $-0.113 * * *(-4.77)$ & $-0.1261 * * *(-6.71)$ & $-0.154 * * *(-5.88)$ \\
\hline$\Delta G D P_{t-1}$ & - & $0.289(0.91)$ & - \\
\hline$F E L E C$ & - & - & $0.175 * * *(5.15)$ \\
\hline $\mathrm{N}$ & 191 & 167 & 191 \\
\hline $\mathrm{R}^{2}$ & 0.609 & 0.619 & 0.656 \\
\hline$\rho$ & 0.773 & 0.706 & 0.729 \\
\hline Wald $\chi^{2}$ & $22.72 * * *$ & $45.07 * * *$ & $34.72 * * *$ \\
\hline
\end{tabular}

Notes: Dependent variable: ELITE; z-statistics are reported in parentheses; * significant at the 0.05 level; ** significant at the 0.005 level; *** significant at the 0.0005 level. 
In model 3, we investigate the influence of our main independent variable, $F E L E C$, which measures the degree to which early democratic elections were free and caused a decisive break with the former regime. FELEC shows the expected positive sign and is strongly significant. Model 3 confirms the crucial role of the first elections after a regime's breakdown, indicating that countries that embarked early and decisively on democratic reforms fared much better with the liberalization of their foreign economic regimes. Latvia and Estonia give a lesson in how to turn one's back on old-fashioned political and economic styles. Both former Soviet republics broke decisively with the communist legacy and at the same time strived for economic integration into the world market. As predicted by our model, both political and economic liberalization went in hand.

The other extreme are countries like Ukraine, Belarus and Uzbekistan, which never really broke with their political past and whose elites tried to prevent political reform. Again in line with our model, a lack of foreign economic reforms parallels political stagnation. Either these countries remained economically closed from the beginning, as Ukraine and Belarus did, or they re-introduced protectionist measures, as was the case for Uzbekistan. Typical countries of the intermediate political transition level (e.g., Mongolia, Albania or Bulgaria) did not implement quick and far-reaching political reforms. When we test the critical juncture argument against the competing hypotheses made in the literature, FELEC remains robust and significant. The five models we present in Table 5 summarize this finding.

Models 4 and 5 test for the role of institutional veto players in conjunction with our critical juncture variable. Presidentialism (IPP) has no significant influence, but its positive sign shows that the more rights a system grants to its president, the more pronounced its foreign economic reforms. The veto player theory, however, is not explicit about the reform effects of presidential regimes. In his seminal book, Tsebelis (2002) discusses the effects of traditional presidential democracies. He is, however, less explicit about presidentialism in newly democratized countries. As the results reported in Table 5 suggest, the veto effect of presidentialism in transition countries is rather convoluted. In Poland and Lithuania, strong presidents faced strong parliaments and should be considered additional veto players. In the presidential regimes of the CIS, however, struggles between parliaments and presidents were frequent (Åslund 2002). This is why presidentialism in these countries correlates with lower degrees of democracy and consequently with less developed institutional checks and balances. The president of Kazakhstan, for example, is in a strong position, but he faces an impotent parliament. ${ }^{8}$ The correct interpretation for the positive sign of IPP is that countries with stronger presidents fare better if one controls for the 


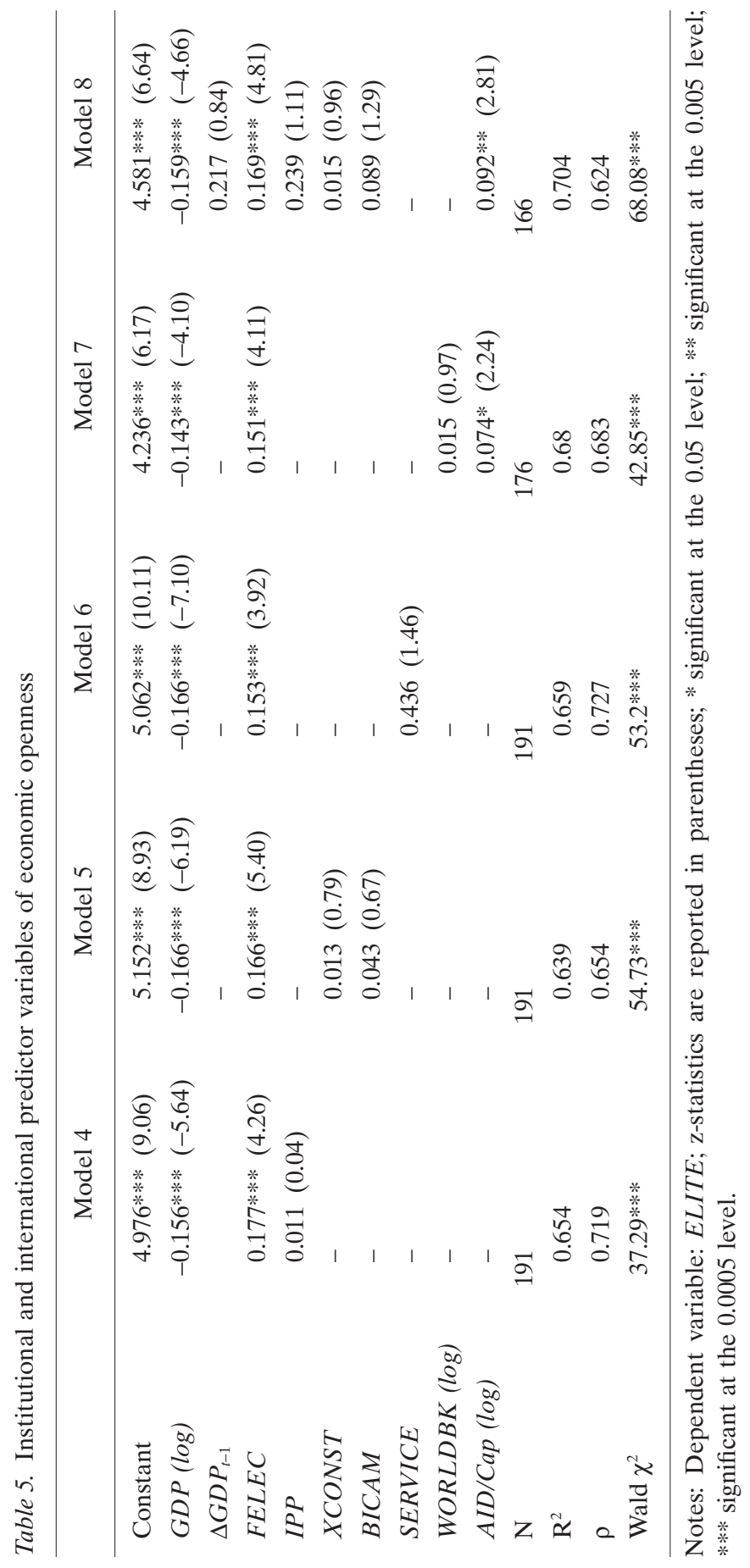


first elections (FELEC) that brought about democratic change; ${ }^{9}$ otherwise, the sign of IPP is negative.

Model 5 tests for the impact of two additional veto player variables (XCONST and BICAM) along with the critical juncture variable. XCONST measures the degree to which executives face institutional constraints, while $B I C A M$ is the dummy variable for bicameral systems. Both variables exhibit the expected positive signs without being significant. Moreover, the critical juncture variable remains robust in model 6; the size and sign of the coefficient remain stable. FELEC and XCONST are correlated, which causes the insignificance of XCONST. When FELEC is left out the regression, XCONST reaches the level of significance. The results of both veto player variables are in line with our refined hypotheses on veto player behaviour. Although there are opponents to economic liberalization, veto players try to liberalize in order to meet the demands of the median voter. Model 5 also contradicts the standard veto player framework in which 'office-seeking' and thus the striving for re-election does not matter. Lack of government autonomy is usually associated with higher degrees of state capture by opposition parties and interest groups. Highly autonomous governments are considered to be a predicament against gridlock. The estimations of our models do not confirm that autocracies possess an advantage. Institutionally constrained governments obviously do not avoid socially painful reforms. On the contrary, they strive for better economic performance and hence are ready to embark on structural reforms. The same relationship holds true for second chambers. Bicameralism is presumed to be an impediment to reform since it offers additional veto points in the political process.

Our results are even more remarkable when we consider that foreign economic reforms produce short-term losers who have strong incentives to oppose these reforms. Again, Estonia, Lithuania and Mongolia serve as examples of countries with particularly powerful veto players that embarked on encompassing foreign economic reforms. By 1999, all three countries belonged to the group with the most liberal foreign economic policies. Even highly industrialized countries in central Europe, like the Czech Republic, managed to open their economies to a considerable degree. This success is far from obvious and largely due to strong executive constraints and a second chamber, which spurred foreign economic reforms. In contrast to other presidential regimes, Kyrgyzstan opted for a second chamber and a stronger institutional veto player structure. This decision turned out to be successful for the liberalization of its foreign economic policies. Kyrgyzstan by far exceeds its neighbours in terms of foreign economic liberalization.

Model 6 contrasts the interest group hypothesis with our critical juncture explanation. Although it is notoriously difficult to measure interest group 
influence, we took the size of the service sector (SERVICE) as a proxy for the strength of its political influence. If we assume a Ricardo-Viner model, the positive sign of SERVICE indicates that services lobby for more open foreign economic regimes because they gain more from free trade than the manufacturing sector. When tested without our critical juncture variable, the interest group indicator exerts a highly significant influence. We conclude from this that the impact of the third sector is partly a function of previous critical junctures.

Model 7 assesses the impact of international financial aid on foreign economic liberalization. We test especially for the role of World Bank credits (WORLDBK $\log$ ) and the amount of international aid per capita (AID/Cap $\log$ ). Our results show that both World Bank and international aid help liberalize the external sector; in the case of international aid, even significantly. The results partly confirm the standard expectations of conditional lending (Guitian 1995). Moreover, we included a dummy for those countries who strived for European Union (EU) accession. The rationale behind this was the assumption that the EU should exert a strong influence on the economic reform pace of the transition countries. The EU dummy, however, turned out insignificant when tested along with World Bank loans and international aid.

Model 8 tests our main independent variables in a broader conceptual framework. We include variables from each theoretical building block and contrast them with FELEC, the critical juncture variable. In addition to our baseline model $(G D P \log )$, we controlled for economic crisis $\left(\triangle G D P_{t-1}\right)$, veto players (IPP $, X C O N S T, B I C A M)$ and international aid $(A I D / C a p l o g) .{ }^{10}$ The robust results confirm that our theoretical model grasps an important part of the political economy of trade liberalization. FELEC keeps its sign and level of significance. The veto player variables IPP, XCONST and BICAM keep their signs too without losing significance, which might at least partly be due to the rather strong correlation between FELEC and XCONST. ${ }^{11}$ Only international aid $(A I D / C a p \log )$ turns out significant and underscores the importance of international backing for foreign economic reforms. The fit of all models is good. The high positive values of $\rho$ indicate positive temporal autocorrelation and justify the estimation by a first-order autocorrelation correction.

\section{Conclusion}

One puzzle in comparative politics is the question to what degree domestic institutions contribute to the economic success of a state. The proponents of the modernization thesis maintain that the relationship works both ways, with 
democracy being both a cause and a condition of economic growth. Przeworski et al. (2000) have recently taken up this hypothesis and shown that only the economic conditions of democracy receive empirical support. Our analysis has pursued a similar objective and tried to explore the relative importance of both political and economic determinants of economic openness in the transition countries. We have particularly explored whether or not institutionally empowered agents have the ability to block the process of economic reform. Our analysis extends this so-called 'veto player' literature and suggests that the degree of foreign economic openness crucially depends on the mode of transition. A non-cooperative game model, which we develop here, shows the conditions under which a country opts for a double reform, decides to open up either its political or economic system or prefers to stay with the status quo. Such an enlarged perspective, which links the question of constitutional choice to policy decisions, makes sense for an analysis of transition countries. As we have argued, these states decided about both issues simultaneously. We used this feature to derive hypotheses that link the early decisions in the transition process to the question of policy reform.

Our transition mode argument receives empirical support in our regression models. Although institutional veto players correlate strongly with the level of economic openness, we believe that the important aspect is whether or not a state has succeeded in at least limiting the influence of powerful distributional coalitions in its first founding elections. The credibility of the threats of the 'softliners' within the party apparatus or the median voter is key to our understanding the transformation process. A double transition, in which both democratic and economic reforms are implemented, is only likely in situations in which a powerful civil society and accommodating elite face a hardliner government.

\section{Acknowledgments}

We would like to thank Robert Franzese, Mark Hallerberg, Christian Martin, Thomas Plümper, and Neil Robinson for their helpful comments, and Doreen Spörer for her assistance in creating the ELITE data set. We gratefully acknowledge the financial assistance of the Volkswagen Foundation. 


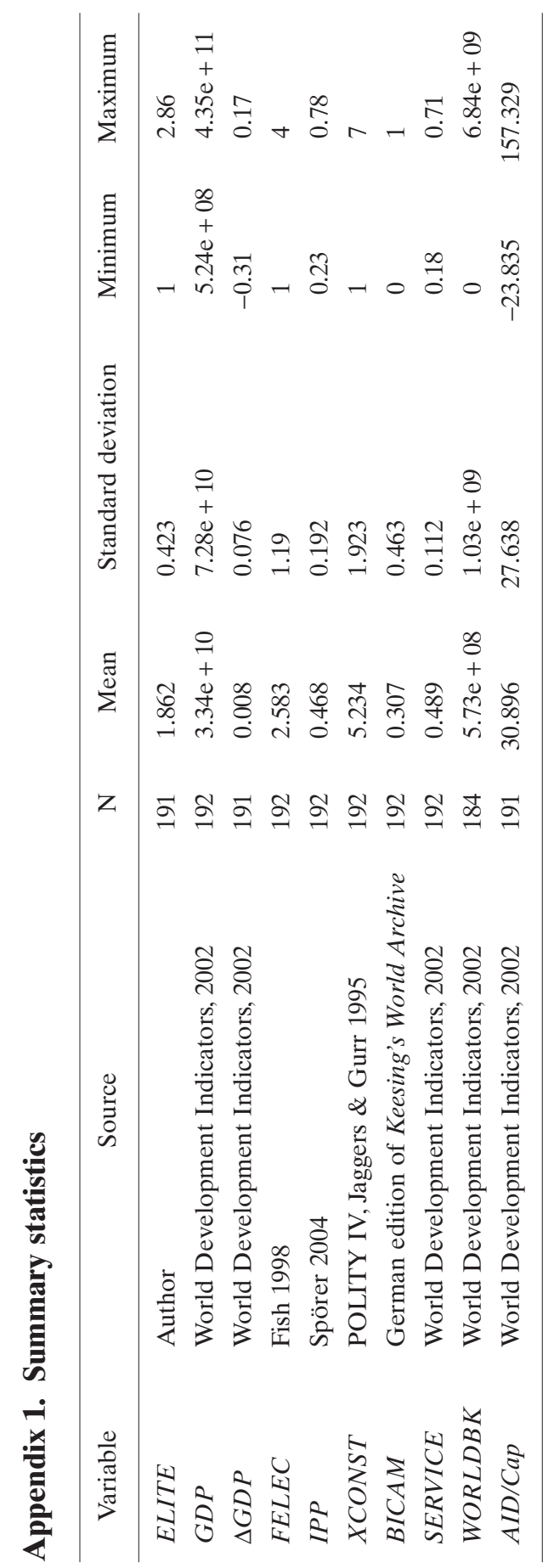




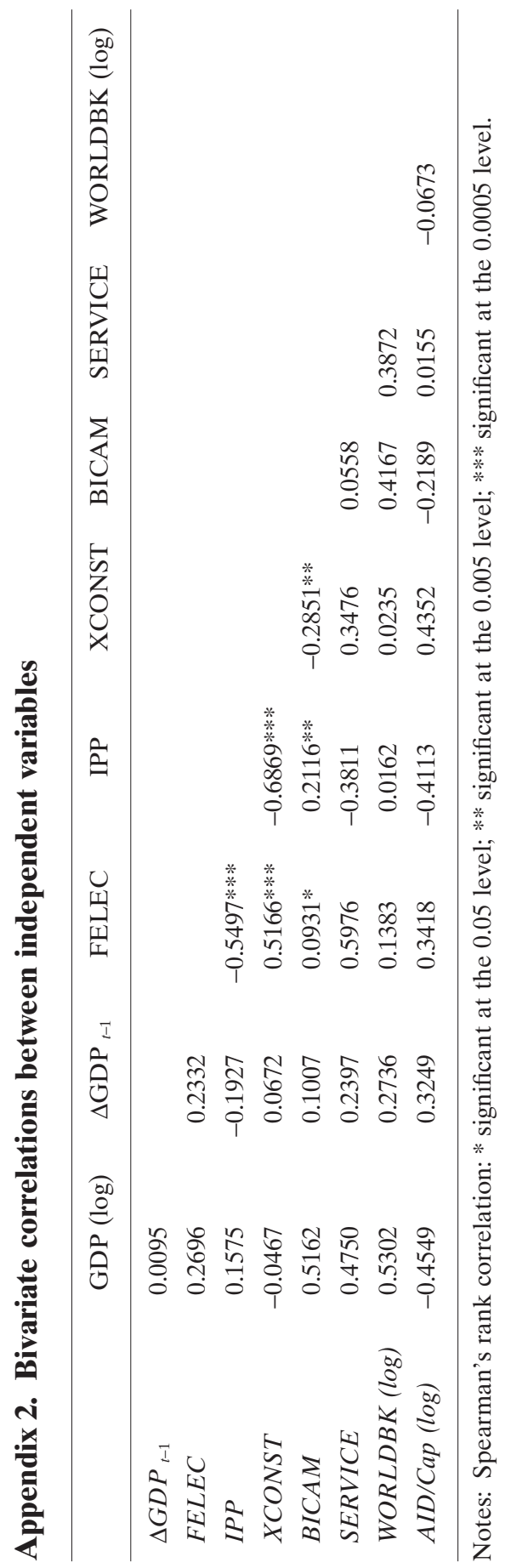




\section{Notes}

1. We should mention two other schools of thought. Fernandez \& Rodrik (1991) examine how voters rationally decide against reform. Although the electorate in general profits from the liberalization strategies, individual voters have an incentive to block the reform measures because they cannot know whether they will belong to the winners or losers. Some political geographers have also claimed that some states are lucky enough to be situated in a capitalist rather than an étatiste region (Kopstein \& Reilly 2000). We believe that the proponents of the 'born lucky' argument need to properly specify the conditions under which geographical distance affects human behaviour. Moreover, we do not present the 'asymmetric information' arguments because of our inability to test them empirically.

2. This suggests that democracies should be more open than autocracies (see also Hausken et al. 2002).

3. Please note that we exclude by assumption the possibility that the hardliner faction gives in to the demands of the median voter, but refuses to accept the wishes of the softliner faction.

4. The database does not include Bosnia-Herzegovina, Serbia-Montenegro, Tajikistan and Turkmenistan because of lack of data. This should, however, not yield a selection bias as three of these countries were involved in civil war during a substantial part of the observation period, and Turkmenistan never exhibited significant reform activities.

5. The sub-index for trade regulations contains information about registration requirements, licenses and quotas, repatriation requirements, surrender requirements, export licenses, export taxes, regulations on invisibles transactions, repatriation requirements, and surrender requirements for invisibles transactions. The index for capital regulations embraces information about exchange taxes, foreign exchange accounts held by residents domestically, foreign exchange accounts held by residents abroad, foreign exchange accounts for non-residents, domestic currency accounts permitted for nonresidents, permissions for commercial credits, financial credits, foreign direct investment, and liquidation of foreign direct investment.

6. We also tested for income per capita in order to evaluate the hypothesis that rich countries trade more than poor countries. This relationship has the expected positive sign indicating that rich transition countries are economically more open. Nevertheless, GDP per capita was insignificant in the bivariate model, and we therefore ignored it in our estimations.

7. For the transition countries, this relationship can be explained by the sequencing literature (Funke 1993; Bhattacharya 1997). If the countries followed more or less a coherent overall reform strategy, they stabilized their economies in the first place and restructured their foreign economic regimes in a latter stage. Opening the economy for the world market without a certain degree of macroeconomic stabilization bears the risk of monetary crises and capital flight.

8. The Spearman's rank correlation of presidentialism $(I P P)$ and institutional executive constraints (XCONST) for the CIS countries is -0.78 .

9. If we control only for the size of the economy (GDP $\log$ ), IPP is positive and strongly significant.

10. We did not consider the interest group variable SERVICE because it did not improve the model fit. Collinearity also prevents us from including World Bank loans (WORLDBK log). Calculation of the variance inflation factors for model 8 shows that the remaining variables are not heteroscedastic.

11. The Spearman's rank correlation of FELEC and XCONST is 0.52 . 


\section{References}

Acemoglu, D. \& Robinson, J. (2001). A theory of political transitions. American Economic Review 91: 938-963.

Achen, C. (2000). Why Lagged Dependent Variables can Suppress the Explanatory Power of Other Independent Variables. Paper presented at the annual meeting of the Political Methodology Section of the American Political Science Association, Los Angeles, July.

Alesina, A. \& Drazen, A. (1991). Why are stabilizations delayed? American Economic Review 81: 1170-1188.

Alesina, A. \& Wacziarg, R. (1998). Openness, country size and the government. Journal of Public Economics 69: 305-321.

Åslund, A. (2002). Building capitalism: The transformation of the former Soviet Bloc. Cambridge: Cambridge University Press.

Balcerowicz, L. (1994). Understanding post-communist transitions. Journal of Democracy 5: 75-89.

Bates, R.H. \& Krueger, A.O. (1993). Generalizations arising from the country studies. In R.H. Bates \& A.O. Krueger (eds), Political and economic interactions in economic policy reform: Evidence from eight countries. Oxford: Blackwell.

Beck, N. \& Katz, J.N. (1995). What to do (and not to do) with time-series cross-section data. American Political Science Review 89: 634-647.

Ben-Zion, U. \& Eytan, Z. (1974). On money, votes and policy in a democratic society. Public Choice 17: 1-10.

Bhattacharya, R. (1997). Pace, sequencing and credibility of structural reforms. World Development 25: 1045-1061.

Bodenstein, T., Plümper T. \& Schneider, G. (2003). Two sides of economic openness: Nontariff barriers to trade and capital controls in transition countries, 1993-2000. Communist and Post-Communist Studies 36: 231-243.

Bordo, M.D. \& Schwartz, A.J. (2000). Measuring real-economic effects of bailouts: Historical perspectives on how countries in financial distress have fared with and without bailouts (National Bureau of Economic Research Working Paper 7701). Cambridge, MA: NBER.

Bueno de Mesquita, B., Morrow, J.D. \& Siverson, R.M. (2002). Political institutions, policy choice and the survival of leaders. British Journal of Political Science 32: 559-590.

Bueno de Mesquita, B. et al. (1999). An institutional explanation of the democratic peace. American Political Science Review 93: 791-807.

Bunce, V. (2000). Comparative democratization: Big and bounded generalizations. Comparative Political Studies 33: 703-734.

Bunce, V. (2003). Rethinking recent democratization: Lessons from postcommunist experience. World Politics 55: 167-192.

Burnside, C. \& Dollar, D. (2000). Aid, policies and growth. American Economic Review 90: 847-868.

Collier, P. (1997). The failure of conditionality. In C. Gwin \& J.M. Nelson (eds), Perspectives on aid and development. Baltimore, MD: Johns Hopkins University Press.

Colomer, J.M. (1991). Transitions by agreement: Modeling the Spanish way. American Political Science Review 85: 1283-1302.

Colomer, J.M. (1995). Strategies and outcomes in Eastern Europe. Journal of Democracy 6: $74-85$.

Dabrowski, M. (1998). Western aid conditionality and the post-communist transition, 19901994. Journal of Policy Reform 2: 169-193. 
De Melo, M. et al. (1997). Circumstance and choice: The role of initial conditions and policies in transition economies (World Bank Policy Research Working Paper 1866). Washington, DC: World Bank.

Dicks-Mireaux, L., Mecagni, M. \& Schadler, S. (2000). Evaluating the effect of IMF lending to low-income countries. Journal of Development Economics 61: 495-526.

Drazen, A. (2000). Political economy in macroeconomics. Princeton, NJ: Princeton University Press.

Drazen, A. \& Easterly, W. (2001). Do crises induce reform? Simple empirical tests of conventional wisdom. Economics and Politics 13: 129-157.

Easter, G. (1997). Preference for presidentialism: Postcommunist regime change in Russia and the NIS. World Politics 49: 184-211.

European Bank for Reconstruction and Development (EBRD) (1993-2000). Transition report (various issues). London: EBRD.

European Bank for Reconstruction and Development (EBRD) (1999). Transition Report: Ten Years of Transition. London: EBRD.

Fernandez, R. \& Rodrik, D. (1991). Resistance to reform: Status quo bias in the presence of individual-specific uncertainty. American Economic Review 81: 1146-1155.

Fish, S.M. (1998). The determinants of economic reform in the post-communist world. East European Politics and Societies 12: 31-78.

Fish, S.M. (1999). Postcommunist subversion: Social science and democratization in East Europe and Eurasia. Slavic Review 58: 794-823.

Frye, T. (2002a). Capture or exchange? Business lobbying in Russia. Europe-Asia Studies 54: $1017-1036$.

Frye, T. (2002b). The perils of polarization: Economic performance in the postcommunist world. World Politics 54: 308-337.

Frye, T. \& Mansfield, E.D. (2003). Fragmenting protection: The political economy of trade policy in the post-communist world. British Journal of Political Science 33: 635-657.

Frye, T. \& Mansfield, E.D. (2004). Timing is everything: Elections and trade liberalization in the postcommunist world. Comparative Political Studies 37: 371-398.

Funke, N. (1993). Timing and sequencing of reforms: Competing views and the role of credibility. Kyklos 46: 336-362.

Gordon, C. (2000). Institutions, economic interests and the stalling of economic reform. In N. Robinson (ed.), Institutions and political change in Russia. New York: St Martin's Press.

Grossman, G.M. \& Helpman, E, (2001). Special interest politics. Cambridge, MA: MIT Press.

Guitian, M. (1995). Conditionality: Past, present, future. IMF Staff Papers 42: 792-835.

Gujarati, D.N. (2003). Basic econometrics (4th edn). Boston, MA: McGraw-Hill.

Haggard, S. \& Kaufman, R. (1995). The political economy of democratic transitions. Princeton, NJ: Princeton University Press.

Haggard, S. \& Webb, S. (eds) (1994). Voting for reform: Democracy, political liberalization and economic adjustment. New York: Oxford University Press.

Harrigan, J. (1996). The Bretton Woods institutions in developing countries: Bêtes noires or toothless tigers? World Economy 19: 765-779.

Hausken, K., Plümper, T. \& Schneider, G. (2002). The Trilemma of the Protectionist Autocrat: Assessing the Link between Democratisation, Government Division and Foreign Economic Liberalisation. Unpublished paper, University of Konstanz.

Hellman, J.S. (1998). Winners take all: The politics of partial transition. World Politics 50: 203-234. 
Hellman, J.S. \& Schankerman, M. (2000). Intervention, corruption and capture: The nexus between enterprise and the state. Economics of Transition 8: 545-576.

Hellman, J.S., Jones, G. \& Kaufmann, D. (2003). Seize the state, seize the day: State capture and influence in transition economies. Journal of Comparative Economics 31: 751-773.

Jaggers, K. \& Gurr, T.R. (1995). Tracking democracy's third wave with the Polity III data. Journal of Peace Research 32: 469-482.

Kitschelt, H. et al. (eds) (1999). Continuity and change in contemporary capitalism. Cambridge: Cambridge University Press.

Klingemann, H.-D. \& Taylor, C.L. (eds) (1995-2002). Founding elections in Eastern Europe. Vols 1-9. Berlin: Edition Sigma.

Kopstein, J.S. \& Reilly, D.A. (2000). Geographic diffusion and the transformation of the postcommunist world. World Politics 53: 1-37.

Lewis, P.G. (1997). Theories of democratization and patterns of regime change in Eastern Europe. Journal of Communist Studies and Transition Politics 13: 4-26.

Lewis, P.G. (2000). Political parties in post-communist Eastern Europe. London: Routledge.

Lijphart, A. (1999). Patterns of democracy: Government forms and performance in thirty-six countries. London: Yale University Press.

Lundborg, P. (1998). Foreign aid and international support as gift exchange. Economics and Politics 10: 127-141.

Magee, S.P., Brock, W.A. \& Young, L. (1989). Black hole tariffs and endogenous policy theory: Political economy in general equilibrium. Cambridge: Cambridge University Press.

Mair, P. (1997). Party system change: Approaches and interpretations. Oxford: Oxford University Press.

Martinelli, C. \& Tommasi, M. (1997). Sequencing of economic reforms in the presence of political constraints. Economics and Politics 9: 115-131.

McFaul, M. (1995). State power, institutional change and the politics of privatization in Russia. World Politics 47: 210-243.

McFaul, M. (2002). The fourth wave of democracy and dictatorship. Noncooperative transitions in the postcommunist world. World Politics 54: 212-244.

Migdal, J.S., Kohli, A. \& Shue, V. (eds) (1994). State power and social forces. Cambridge: Cambridge University Press.

Mosley, P. (1992). A theory of conditionality. In Development finance and policy reform: Essays in the theory and practice of conditionality in less developed countries. New York: St Martin's Press.

Mosley, P., Harrigan, J. \& Toye, J. (1991). Aid and power: The World Bank and policy-based lending. Vol. 1. London: Routledge.

Munck, G.L. \& Skalnik Leff, C. (1997). Modes of transition and democratization: South America and Eastern Europe in comparative perspective. Comparative Politics 29:343362.

Olson, M. (1982). The rise and decline of nations: Economic growth, stagflation and social rigidities. London: Yale University Press.

Olson, M. (1996). Big bills left on the sidewalk. Why some nations are rich and others are poor. Journal of Economic Perspectives 10: 3-24.

Olson, M. (2000). Power and prosperity: Outgrowing communist and capitalist dictatorships. New York: Basic Books.

Persson, T., Roland, G. \& Tabellini, G. (1997). Separation of powers and political accountability. Quarterly Journal of Economics 112: 1163-1202. 
Plümper, T., Tröger, V. \& Manow, P. (2005). Panel data in comparative politics: Linking method to theory. European Journal of Political Research 44(2): 327-354.

Przeworski, A. (1991). Democracy and the market: Political and economic reforms in Eastern Europe and Latin America. Cambridge: Cambridge University Press.

Przeworski, A. et al. (2000). Democracy and development: Political institutions and well-being in the world, 1950-1990. Cambridge: Cambridge University Press.

Quinn, D. (1997). The correlates of change in international financial regulation. American Political Science Review 91: 531-551.

Sachs, J. (1989). Conditionality, debt relief and developing country debt crisis. In Developing country debt and economic performance. Vol. 1: The international financial system. Chicago, IL: University of Chicago Press.

Spörer, D. (2004). Ausmaß, Strukturen und Implikationen präsidialer Macht im postkommunistischen Raum. Schweizerische Zeitschrift für Politikwissenschaft 10: 157-179.

Stone, R.W. (2002). Lending credibility: The International Monetary Fund and the postcommunist transition. Princeton, NJ: Princeton University Press.

Taylor, L. (1997). The revival of the liberal creed: The IMF and the World Bank in a globalized economy. World Development 25: 145-152.

Tsebelis, G. (1995). Decision making in political systems: Veto players in presidentialism, parliamentarism, multicameralism and multipartyism. British Journal of Political Science 25: 289-325.

Tsebelis, G. (1999). Veto players and law production in parliamentary democracies: An empirical analysis. American Political Science Review 93: 591-608.

Tsebelis, G. (2002). Veto players: How political institutions work. Princeton, NJ: Princeton University Press.

World Bank (2002). World development indicators. Washington, DC: World Bank.

Address for correspondence: Thilo Bodenstein, Jean Monnet Centre of Excellence, Free University of Berlin, Ihnestrasse 22, D-14195 Berlin, Germany. Tel.: + 4930838 56275; Fax: +49 30838 52357; E-mail: t.bodenstein@jmc-berlin.org 